\title{
OCENA ATAKU NA SZPITAL W KUNDUZIE W ŚWIETLE MIĘDZYNARODOWEGO PRAWA HUMANITARNEGO
}

Słowa kluczowe: międzynarodowe prawo humanitarne, atak na szpital, zasady ostrożności, zasada rozróżniania, cele wojskowe

Keywords: international humanitarian law, attack on the hospital, precautionary principles, principle of distinction, military objectives

\section{WPROWADZENIE}

W

dniu 3 października 2015 r. miał miejsce atak amerykańskich sił zbrojnych na szpital prowadzony przez organizację pozarządową Lekarze Bez Granic (Médecins Sans Frontières), który znajdował się w afgańskim mieście Kunduz. Amerykanie zbombardowali szpital, zabijając co najmniej dwunastu członków Lekarzy Bez Granic i dziesięciu pacjentów szpitala oraz raniąc kolejnych trzydzieści siedem osób. Atak stanowił część operacji wojskowej odbicia zajętego przez talibów miasta Kunduz². Szpital stanowił jedyne miejsce tego typu w Kunduzie i w samym 2014 r. udzielił

${ }^{1}$ Katedra Prawa Międzynarodowego i Europejskiego, Wydział Politologii i Studiów Międzynarodowych, Uniwersytet Mikołaja Kopernika, e-mail: aszpak@umk.pl.

2 J. Horowitz, Was the Kunduz Strike a War Crime?, blog Just Security, dostępne na stronie internetowej: https://www.justsecurity.org/26569/kunduz-strike-war-crime/ (dostęp: 20.10.2015). 
pomocy medycznej ponad 22 tysiącom ludzi ${ }^{3}$. Lekarze Bez Granic oskarżyli USA o popełnienie zbrodni wojennej. Również wielu komentatorów wskazało na taką możliwość. Organizacja zażądała przeprowadzenia międzynarodowego, niezależnego śledztwa i ukarania osób odpowiedzialnych. Nie przyjęła przy tym przeprosin złożonych przez Prezydenta USA Baracka

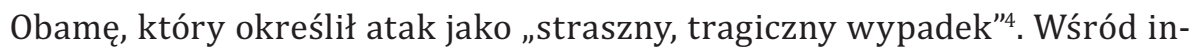
nych ciał i instytucji, które zabrały głos należy wymienić Wysokiego Komisarza Narodów Zjednoczonych ds. Praw Człowieka Zeid'a al-Hussein'a. Stwierdził on, że atak był tragiczny, niewybaczalny, prawdopodobnie kryminalny, i możliwe, że stanowił zbrodnię wojenną. Również Międzynarodowy Komitet Czerwonego Krzyża (MKCK) potępił atak ${ }^{5}$.

Podstawowe pytanie, na które postaram się odpowiedzieć w tym krótkim artykule, brzmi: czy amerykańskie zbombardowanie szpitala w Kunduzie stanowiło zbrodnię wojenną? W pierwszym rzędzie konieczne jest określenie charakteru konfliktu zbrojnego trwającego w Afganistanie oraz prawa mającego zastosowanie i rządzącego ochroną szpitali cywilnych. Następnie należy wskazać, jakie reguły rządzą atakami na cele wojskowe. Na tym tle przeanalizowane zostaną amerykańskie działania i dokonana zostanie ich ocena prawna w świetle międzynarodowego prawa humanitarnego. Naturalnie nie jest możliwa ostateczna ocena tych działań, ponieważ nie dysponujemy wszystkimi danymi, koniecznymi dla przeprowadzenia takiej oceny. Zależy ona od wielu czynników faktycznych, które na chwilę obecną nie zostały jeszcze ustalone. Stąd tak ważne jest przeprowadzenie niezależnego śledztwa w tym przedmiocie, o czym również wspomnę w zakończeniu niniejszego artykułu.

${ }^{3}$ P. Grzebyk, Zbombardowanie szpitala w Kunduz - zbrodnia, która trzeba wyjaśnić (update i poprawka), blog Przegląd Prawa Międzynarodowego, dostępne na stronie internetowej: http://przegladpm.blogspot.com/2015/10/kunduz-zbrodnia-ktora-trzeba-wyjasnic.html (dostęp: 20.10.2015).

${ }^{4}$ F. Ni Aoláin, When Sorry Is Not Enough (or Makes Things Worse), blog Just Security, dostępne na stronie internetowej: https://www.justsecurity.org/26718/or-worse/ (dostęp: 20.10.2015); T. Walker, Kunduz hospital bombing: President Obama apologises for US air strike that killed 12 aid workers and 10 patients, dostępne na stronie internetowej: http://www.independent.co.uk/news/world/americas/kunduz-hospital-bombing-president-obama-apologises-for-us-airstrike-that-killed-12-aid-workers-and-a6685341.html (dostęp: 20.10.2015).

${ }^{5}$ J. Horowitz, op.cit. 
:::: Agnieszka Szpak, Ocena ataku na szpital w Kunduzie...

\section{Charakter konfliktu zbrojnego I prawo mające WOBEC NIEGO ZASTOSOWANIE}

Mimo różnych kontrowersji i wątpliwości co do charakteru konfliktu zbrojnego w Afganistanie można uznać, że po obaleniu talibów i dojściu do władzy nowego rządu, który wspólnie z ISAF (International Security Assistance Force) walczy z talibami, konflikt zbrojny z międzynarodowego (między Afganistanem a USA) przekształcił się w niemiędzynarodowe (rząd Afganistanu wspierany przez USA przeciwko talibom). Konsekwencją tego jest zastosowanie do niego międzynarodowego prawa humanitarnego zawartego we wspólnym dla czterech konwencji genewskich z 1949 r. artykule $3^{6}$ oraz II Protokole dodatkowym do Konwencji genewskich, dotyczącym ochrony ofiar niemiędzynarodowych konfliktów zbrojnych z 1977 r.7, których Afganistan jest stronąi . Ponadto należy pamiętać o zwyczajowym międzynarodowym prawie humanitarnym, którego dobrym źródłem poznawczym jest Studium MKCK z 2005 r. ${ }^{9}$

Wspólny art. 3 stanowi, że „osoby nie biorące bezpośrednio udziału w działaniach wojennych, włącznie z członkami sił zbrojnych, które złożyły broń, oraz osobami, które stały się niezdolne do walki na skutek choroby, ran, pozbawienia wolności lub z jakiegokolwiek innego powodu, będą we wszelkich okolicznościach traktowane w sposób humanitarny, bez czynienia żadnej różnicy na ich niekorzyść z powodu rasy, koloru skóry, religii lub wiary, płci, urodzenia lub majątku, ani z żadnych innych analogicznych powodów". Przepis ten wyraźnie zakazuje atakowania w jakikolwiek sposób osób, które stały się niezdolne do walki na skutek ran i choroby, bez względu na to czy są to osoby cywilne, czy też członkowie sił zbrojnych lub bo-

${ }^{6}$ Cztery konwencje genewskie są dostępne w: Dz.U. z 1956 r., nr 38, poz. 171, załącznik. Przywołując wspólny art. 3, będę odwoływać się do tego źródła.

${ }^{7}$ II Protokół dodatkowy z 1977 r. jest dostępny w: Dz.U. z 1992 r., nr 41, poz. 175, załącznik.

${ }^{8}$ Zob. wykaz państw stron na stronie MKCK: https://www.icrc.org/applic/ihl/ ihl.nsf/States.xsp?xp_viewStates=XPages_NORMStatesParties\&xp_treatySelected $=475$ (dostęp: 20.10.2015).

9 J.-M. Henckaerts, L. Doswald-Beck, Customary International Humanitarian Law. vol. I: Rules, Cambridge University Press, Cambridge 2005. 
jownicy walczący po niepaństwowej stronie konfliktu. Ranni i chorzy korzystają z ochrony.

Przepisy te zostały uzupełnione i rozwinięte we wspomnianym II Protokole dodatkowym. Istotne $\mathrm{w}$ tym przedmiocie są art. 4 (podstawowe gwarancje), art. 7 (ochrona rannych i chorych), art. 9 (ochrona personelu medycznego), art. 11 (ochrona formacji medycznych), art. 12 (znak rozpoznawczy). Zgodnie z tymi przepisami, „wszyscy ranni, chorzy i rozbitkowie korzystają z poszanowania i ochrony, niezależnie od tego, czy uczestniczyli w konflikcie zbrojnym” (art. 7) ${ }^{10}$; , personel medyczny i duchowny powinien być szanowany i chroniony ” (art. 9) ${ }^{11}$; „medyczne formacje i środki transportu medycznego korzystają zawsze z poszanowania i ochrony i nie mogą być przedmiotem ataków. Ochrona przysługująca medycznym formacjom i środkom transportu może ustać tylko wtedy, gdy są one używane, poza ramami swych zadań humanitarnych, do działań wrogich. Niemniej ochrona może ustać dopiero po bezskutecznym ostrzeżeniu ustalającym, jeśli to możliwe, rozsądny termin”12. Warto też dodać, że zgodnie z art. 12, „[p]od kontrolą właściwej uprawnionej władzy personel medyczny i duchowny oraz medyczne formacje i środki transportu powinny używać znaku rozpoznawczego czerwonego krzyża, czerwonego, półksiężyca lub czerwonego kryształu na białym tle. Powinien on być szanowany we wszystkich okolicznościach i nie może być nadużywany"13. Przepisy te stanowią również odzwierciedlenie międzynarodowego prawa zwyczajowego i jakie takie są wiążące dla wszystkich stron konfliktu zbrojnego ${ }^{14}$.

\section{Reguty PODEJMOWANIA ATAKU NA CELE WOJSKOWE}

Jak zostało wspomniane, nie wolno atakować szpitali, nawet jeśli leczeni są w nich żołnierze wrogiej strony. Zupełnie wyjątkowo można zaatakować szpital, jeśli jest on wykorzystywany, poza ramami swych zadań hu-

10 II Protokół dodatkowy z 1977 r. w: Dz.U. z 1992 r., nr 41, poz. 175, załącznik.

11 Ibidem.

12 Ibidem.

${ }^{13}$ Ibidem. Zob. też: A. Szpak, Międzynarodowe prawo humanitarne, Wydawnictwo Naukowe UMK, Toruń 2014, s. 291-292.

14 Zob. zasady 25, 27, 28, 30 Studium MKCK - J.-M. Henckaerts, L. Doswald-Beck, op.cit., s. 78-104. 
:::: Agnieszka Szpak, Ocena ataku na szpital w Kunduzie...

manitarnych, do działań wrogich. Jednak nawet wtedy ochrona może ustać dopiero po bezskutecznym ostrzeżeniu ustalającym, jeśli to możliwe, rozsądny termin. Natomiast w przedmiocie podejmowania ataków na cele wojskowe kluczowe są środki ostrożności, które powinny zostać podjęte w takiej sytuacji. W przypadku międzynarodowego konfliktu zbrojnego środki te zostały sformułowane expressis verbis $\mathrm{w}$ art. 57 I Protokołu dodatkowego, natomiast II Protokół dodatkowy takich reguł wprost nie formułuje, jednak powszechnie się uważa, że stanowią one prawo zwyczajowe i jako takie są wiążące dla wszystkich państw świata oraz innych stron konfliktów zbrojnych ${ }^{15}$. Zgodnie z zasadą 15 Studium MKCK, „[w] toku prowadzenia operacji wojskowych należy stale troszczyć się o oszczędzanie ludności cywilnej, osób cywilnych oraz dóbr o charakterze cywilnym. Należy przedsięwziąć wszystkie praktycznie możliwe środki ostrożności w celu uniknięcia, a przynajmniej sprowadzenia do minimum, nie zamierzonych strat w życiu ludzkim wśród ludności cywilnej, ranienia osób cywilnych i szkód w dobrach o charakterze cywilnym” ${ }^{16}$. Ponadto, „każda ze stron konfliktu powinna uczynić wszystko, co jest praktycznie możliwe, dla sprawdzenia, czy cele ataku są celami wojskowymi" (zasada 16$)^{17}$. Zgodnie z zasadami 17 i 18, „każda ze stron konfliktu powinna przedsięwziąć wszystkie praktycznie możliwe środki ostrożności w celu uniknięcia, a przynajmniej sprowadzenia do minimum, nie zamierzonych strat w życiu ludzkim wśród ludności cywilnej, ranienia osób cywilnych oraz szkód w dobrach o charakterze cywilnym” oraz „w celu dokonania oceny tego, czy dany atak może spowodować nie zamierzone straty w życiu ludzkim wśród ludności cywilnej, ranienia osób cywilnych oraz szkody w dobrach o charakterze cywilnym, które byłyby nadmierne w stosunku do oczekiwanej konkretnej i bezpośredniej korzyści wojskowej"18. Kiedy okaże się, że atakowany obiekt nie jest celem wojskowym lub można oczekiwać, że atak wywoła nadmierne straty wśród ludności cywilnej i obiektów cywilnych w porównaniu do oczekiwanej i bezpośredniej korzyści wojskowej (a więc zostanie podjęty

\footnotetext{
15 J.-M. Henckaerts, L. Doswald-Beck, op.cit., zasady 15-21.

16 Ibidem.

17 Ibidem.

${ }^{18}$ Ibidem.
} 
z naruszeniem zasady proporcjonalności), nie należy go podejmować, a już podjęty należy przerwać (zasada 19) ${ }^{19}$.

\section{Atak na szpital w Kunduzie - czy naruszone zostaky NORMY MIĘDZYNARODOWEGO PRAWA HUMANITARNEGO?}

Nie jest możliwe udzielenie jednoznacznej odpowiedzi na to pytanie, przede wszystkim z powodu zbyt wielu niewiadomych. Na wstępie należy zapytać - jaki obiekt USA chciały zaatakować? Jeśli celem ataku był rzeczywiście szpital, to niewątpliwie doszło do naruszenia międzynarodowego prawa humanitarnego, co stanowi jednocześnie zbrodnię wojenną. Zgodnie z art. 8 (2) (e) (iv) Statutu Międzynarodowego Trybunału Karnego (MTK), zbrodnią wojenną popełnianą w niemiędzynarodowym konflikcie zbrojnym jest „zamierzone kierowanie ataków na [...] szpitale oraz miejsca, gdzie gromadzeni są ranni i chorzy, pod warunkiem że nie są one celami wojskowymi" ${ }^{20}$. Bez znaczenia byłby fakt udzielania w szpitalu w Kunduzie pomocy medycznej rannym i chorym należącym do wroga. Należy zauważyć, że organizacja Lekarze Bez Granic potwierdziła, że wiele razy dzieliła się z siłami zbrojnymi USA w Afganistanie informacjami na temat położenia szpitala, w tym ostatni raz 30 września, a więc na trzy dni przed atakiem ${ }^{21}$. Wydaje się jednak niewiarygodne, żeby Amerykanie celowo atakowali szpital $^{22}$. Oni sami na początku stwierdzili, że atak na szpital w Kunduzie stanowił pomyłkę, a następnie gen. John F. Campbell powiedział, że atak był „decyzją podjętą zgodnie z łańcuchem dowodzenia"23.

Druga możliwość obejmuje atak na inny cel - legalny cel wojskowy, np. talibów stacjonujących w pobliżu szpitala, o którym atakujący nie wiedzieli. W tej sytuacji szpital ucierpiałby incydentalnie. Jeżeli tak rzeczywiście było, sami talibowie stanowili legalny cel wojskowy, jednak przy ataku

\footnotetext{
19 Ibidem.

${ }^{20}$ Statut MTK jest dostępny w: Dz.U. z 2003 r., nr 78, poz. 708.

${ }^{21}$ M. Sterio, Strike at Kunduz: Did the United States Violate International Humanitarian Law?, blog IntLawGrrls, dostępne na stronie internetowej: http://ilg2.org/2015/10/08/ strike-at-kunduz-did-the-united-states-violate-international-humanitarian-law/ (dostęp: 20.10.2015).

${ }^{22}$ Zob. również: J. Horowitz, op.cit.

${ }^{23}$ M. Sterio, op.cit.
} 
:::: Agnieszka Szpak, Ocena ataku na szpital w Kunduzie...

na nich należało przedsięwziąć wskazane wyżej środki ostrożności celem zminimalizowania strat w ludności cywilnej i szkód w obiektach cywilnych oraz celem sprawdzenia czy atak nie spowoduje nadmiernych strat w porównaniu do oczekiwanej i bezpośredniej korzyści wojskowej z ataku. Jonathan Horowitz stawia w tym zakresie następujące pytania: czy szpital był oznaczony znakiem Czerwonego Krzyża, np. na dachu? Czy pilot był w stanie ten znak zobaczyć? Jeżeliby USA nie przedsięwzięły takich środków ostrożności, to naruszyły międzynarodowe prawo humanitarne ${ }^{24}$. Nawet gdyby USA atakując talibów nie wiedziały, że w pobliżu znajduje się szpital, ich obowiązki w zakresie środków ostrożności byłyby podobne. Zawsze należy sprawdzić czy atakowany obiekt jest celem wojskowym, czy w pobliżu nie znajdują się osoby i/lub obiekty cywilne, obiekty chronione jak właśnie szpital. Jeśli dowodzący amerykańską operacją takich środków ostrożności nie podjęli, naruszyli międzynarodowe prawo humanitarne.

Jeśli z kolei Amerykanie jako cel ataku postawili sobie talibów, mając przy tym świadomość, że szpital ucierpi jako collateral damage (straty uboczne), innymi słowy świadomie zdecydowali się poświęcić osoby cywilne, rannych i chorych oraz personel medyczny dla osiągnięcia określonej korzyści wojskowej, podstawowe pytanie brzmi - czy Amerykanie dokonali oceny proporcjonalności strat do korzyści? Zasada proporcjonalności znajduje zastosowanie przy podejmowaniu ataku na legalny cel wojskowy i wchodzących w grę stratach wśród ludności cywilnej. Zastosowanie przedmiotowej zasady wymaga od tych, którzy planują atak, aby podjęli wskazane wyżej środki ostrożności dla sprowadzenia do minimum strat w ludności cywilnej. Jak zostało już wskazane, powinni oni:

„również powstrzymać się od podjęcia ataku, który mógłby spowodować niezamierzone straty w życiu ludzkim wśród ludności cywilnej, ranienia osób cywilnych, szkody w dobrach o charakterze cywilnym lub takie straty i szkody łącznie, których rozmiary byłyby nadmierne do oczekiwanej konkretnej i bezpośredniej korzyści wojskowej. Gdy okaże się, że cel ataku nie ma charakteru wojskowego lub można oczekiwać, iż atak wywoła niezamierzone straty w życiu ludzkim wśród ludności cywilnej, ranienia osób cywilnych lub szkody w dobrach o charakterze cywilnym albo takie straty i szkody łącznie, których rozmiary by-

${ }^{24}$ Zob. J. Horowitz, op.cit. 
łyby nadmierne w stosunku do oczekiwanej konkretnej i bezpośredniej korzyści wojskowej należy odstąpić od takiego ataku lub go przerwać"25.

Przepis art. 57 I Protokołu dodatkowego jest niewątpliwie odzwierciedleniem zasady proporcjonalności, zgodnie z którą, mimo że z założenia dany atak na obiekt wojskowy jest legalny, to należy go zaniechać, gdy wywoła on lub można oczekiwać, że wywoła nadmierne straty w życiu ludzkim lub szkody w dobrach o charakterze cywilnym, tym samym prowadząc do kwalifikacji danego ataku jako nielegalnego. Należy wyraźnie podkreślić, że zasada proporcjonalności ma zastosowanie w przypadku ataku na cel wojskowy, a nie na osoby lub obiekty cywilne. Osoby te lub obiekty mogą ucierpieć jako collateral damage, czyli incydentalnie. Zasada proporcjonalności w ataku znajduje zastosowanie również do wewnętrznych konfliktów zbrojnych, gdyż odzwierciedla prawo zwyczajowe, na co wyraźnie wskazuje zasada 14 Studium MKCK na temat zwyczajowego międzynarodowego prawa humanitarnego ${ }^{26}$. Wydaje się, że w omawianym przypadku straty w ludności cywilnej były nadmierne w stosunku do oczekiwanej bezpośredniej korzyści wojskowej z ataku na talibów, pamiętając cały czas, że tak naprawdę nie wiemy, co USA rzeczywiście chciały zaatakować. Podobne scenariusze omawia Horowitz w swoim tekście na temat ataków na Kunduz ${ }^{27}$.

Warto zauważyć, że zgodnie ze Statutem MTK zbrodnią wojenną, ale popełnianą tylko w międzynarodowych konfliktach zbrojnych, jest „zamierzone przeprowadzanie ataku ze świadomością, iż atak ten spowoduje przypadkową utratę życia lub zranienie osób cywilnych lub szkodę w obiektach cywilnych [...] które byłyby wyraźnie nadmierne w stosunku do konkretnej, bezpośredniej i całkowitej spodziewanej korzyści wojskowej"28. Przepis ten nie ma swojego odpowiednika na liście zbrodni wojennych popełnianych w niemiędzynarodowych konfliktach zbrojnych. Poza tym musi to być działanie zamierzone, nie wystarczy jedynie brak ostrożności.

\footnotetext{
25 Art. 57 I Protokołu dodatkowego w: Dz.U. z 1992 r., nr 41, poz. 175, załącznik.

${ }^{26}$ Zob. też: A. Szpak, op.cit., s. 52-53.

27 J. Horowitz, op.cit. Zob. też: M. Sterio, op.cit.

${ }^{28}$ Statut MTK, art. 8 (2) (b) (iv).
} 
:::: Agnieszka Szpak, Ocena ataku na szpital w Kunduzie...

Można zadać sobie pytanie - czy atak na cel wojskowy przy rażącym braku zachowania środków ostrożności i z naruszeniem zasady proporcjonalności można uznać za świadomy atak bez rozróżnienia? Ataki bez rozróżnienia są zabronione przez I Protokół dodatkowy (art. 57 i art. 85 (3) (b)). W orzecznictwie Międzynarodowego Trybunału Karnego ds. Zbrodni w byłej Jugosławii poważnego naruszenia zasady proporcjonalności nie traktowano jako odrębnej zbrodni, lecz tylko jako dowód ataków skierowanych przeciwko ludności cywilnej lub cywilnym obiektom ${ }^{29}$. Tak czy inaczej te ostatnie stanowią zbrodnię wojenną.

Milena Sterio odrzuca scenariusz, w którym USA nie wiedziały, że bombardują szpital. Wskazuje m.in. na fakt uzyskania przez siły amerykańskie dokładnych informacji na temat położenia szpitala. Jej zdaniem w świetle tego, co wiemy jest bardzo prawdopodobne, że USA naruszyły prawo humanitarne $^{30}$. Z kolei Cathherine Harwood wskazuje na fakt ciągłych telefonów ze strony Lekarzy Bez Granic do centrum dowodzenia sił amerykańskich i kontynuację ataków przez pół godziny od pierwszych telefonów ${ }^{31}$. Wszystko to może wskazywać na tragiczną pomyłkę ze strony amerykańskich sił zbrojnych, jednak wydaje się to mało wiarygodne, biorąc pod uwagę dane dotyczące lokalizacji szpitala, w posiadaniu których byli Amerykanie. Amerykanie nie dochowali raczej wspomnianych wyżej środków ostrożności

${ }^{29}$ H. Olásolo, Unlawful Attacks in Combat Situations. From the ICTY's Case Law to the Rome Statute, Brill, Lejda-Boston 2008, s. 157. Szerzej o zasadzie proporcjonalności, zob. ibidem, s. 155-188; K. Dorman, Proportionality and Distinction in the International Criminal Tribunal for the Former Yugoslavia, „Australian International Law Journal” 12 (2005), s. 83-98; T. M. Franck, On Proportionality of Countermeasures in International Law, „American Journal of International Law” 102 (2008), s. 723-734; S. Oeter, Comment: Is the Principle of Distinction Outdated?, [w:] International Humanitarian Law Facing New Challenges. Symposium in Honour of Knut Ipsen, red. W. Heintschel von Heinegg, V. Epping, Springer, Berlin-Heidelberg 2007, s. 53-62; T. Stein, Collateral Damage, Proportionality and Individual International Criminal Responsibility, [w:] International Humanitarian Law, s. 157-161.

${ }^{30}$ M. Sterio, op.cit.

${ }^{31}$ C. Harwood, Will the 'Sleeping Beauty' Awaken? The Kunduz Hospital attack and the International Humanitarian Fact-Finding Commission, blog EJIL Talk!, dostępne na stronie internetowej: http://www.ejiltalk.org/will-the-sleeping-beauty-awaken-the-kunduz-hospital-attack-and-the-international-humanitarian-fact-finding-commission/(dostęp: 21.10.2015). 
lub zasady proporcjonalności. Równie niewiarygodne wydaje się, że Amerykanie świadomie zbombardowali szpital w Kunduzie.

\section{KoNIECZNoŚĆ PRZEPROWADZENIA NIEZALEŻNEGo ŚLEDZTWA I UKARANIA OSÓB ODPOWIEDZIALNYCH}

Ze względu na wspomniane wyżej niejasności i skalę tragedii konieczne jest przeprowadzenie międzynarodowego, niezależnego i bezstronnego śledztwa. Na chwilę obecną USA zobowiązały się do przeprowadzenia śledztwa przez Departament Obrony, a więc śledztwa o charakterze wewnętrznym, co do którego bezstronności i niezależności można mieć duże wątpliwości. Jednak Lekarze Bez Granic wezwali do przeprowadzenia śledztwa przez Międzynarodową Komisję Ustalania Faktów (MKUF) z art. 90 I Protokołu dodatkowego ${ }^{32}$.

Zgodnie ze wspomnianym art. 90, każde państwo-strona Konwencji genewskich z 1949 r. może przy podpisaniu, ratyfikowaniu lub przystąpieniu do Protokołu oświadczyć, że uznaje wprost i bez szczególnego porozumienia w stosunku do każdej innej strony, która podejmie takie samo zobowiązanie, właściwość Komisji do badania zarzutów naruszeń prawa humanitarnego tej innej strony. Komisja pełni dwie funkcje: po pierwsze, bada fakty, które mogą być ciężkimi naruszeniami Konwencji genewskich i I Protokołu; po drugie, ułatwia, przez ofiarowanie dobrych usług, powrót do przestrzegania Konwencji i Protokołu. MKUF nie ma kompetencji do wydawania oceny prawnej ustalonych faktów (co do zgodności $\mathrm{z}$ prawem). Jest uprawniona jedynie do stwierdzenia określonego stanu faktycznego osiągającego poziom naruszenia przepisów Konwencji genewskich z 1949 r. lub I Protokołu dodatkowego. Wadą MKUF jest jednak konieczność otrzymania żądania przeprowadzenia badań od strony (niekoniecznie strony konfliktu), aby w ogóle można rozpocząć procedurę ta-

${ }^{32}$ N. Cumming-Bruce, Doctors Without Borders Calls for Inquiry Into Kunduz Hospital Attack, dostępne na stronie internetowej: http://www.nytimes.com/2015/10/08/ world/europe/kunduz-afghanistan-hospital-doctors-without-borders.html?\&moduleDetail =section-news-3\&action=click\&contentCollection=Asia\%20Pacific\&region=Footer\&module $=$ MoreInSection\&version=WhatsNext\&contentID=WhatsNext\&pgtype=article\&_r=0 (dostęp: 21.10.2015). Zob. też: M. Sterio, op.cit. 
:::: Agnieszka Szpak, Ocena ataku na szpital w Kunduzie...

kiego badania. Mimo ogromnego potencjału MKUF w praktyce nie działa; pomimo licznych wysiłków samej Komisji, nie zwrócono się do niej z prośbą o przeprowadzenie badań ${ }^{33}$.

Prawdopodobnie tak samo się stanie i w tym przypadku, jako że ani USA, ani Afganistan nie uznają właściwości komisji (USA nawet nie ratyfikowały I Protokołu dodatkowego). Jak zauważa Harwood, możliwe jest uruchomienie tzw. właściwości Komisji ad hoc, a więc właściwości, dla której nie jest nawet konieczna ratyfikacja I Protokołu dodatkowego. Wystarczy, że jedna ze stron konfliktu wyrazi prośbę o działanie Komisji, a druga ją zaakceptuje. Mimo że art. 90 znajduje się w Protokole dotyczącym konfliktów międzynarodowych, a ten w Afganistanie ma charakter niemiędzynarodowy, MKUF może się zajmować także innymi sytuacjami. Ustęp 2 (d) art. 90 stanowi, że „[w] innych sytuacjach Komisja podejmuje badania na żądanie jednej ze Stron konfliktu jedynie za zgodą innej lub innych zainteresowanych Stron"34. Jak widać przepis ten nie ogranicza się tylko do stron Protokołu czy konwencji genewskich, lecz mówi o stronach konfliktu. Może to obejmować strony konfliktu wewnętrznego. I rzeczywiście, Komisja od samego początku swego istnienia deklarowała gotowość do wykonywania swoich zadań również w kontekście wewnętrznych konfliktów zbrojnych. W takim przypadku potrzebna byłaby także zgoda talibów jako strony konfliktu ${ }^{35}$. Jest jednak mało prawdopodobne, aby Komisja taką zgodę uzyskała. Nawet jeśli talibowie udzieliliby jej, to USA raczej tego nie zrobi.

W związku z tym, że nie udało się zaangażować MKUF, powszechnie wskazywano, że USA powinny same powołać lub zgodzić się na powołanie komisji lub zespołu niezależnych i bezstronnych międzynarodowych ekspertów, którzy wyjaśnią stan faktyczny i dokonają prawnej oceny wydarzeń w Kunduzie. Konieczne byłoby także pociągnięcie do odpowiedzialności osób odpowiedzialnych za ten atak oraz zadośćuczynienie i odszkodowanie dla ofiar i ich bliskich. W kwietniu 2016 r. USA upubliczniły raport ze śledz-

${ }^{33}$ Zob. A. Szpak, op.cit., s. 360-362; E. Mikos-Skuza, P. Grzebyk, Międzynarodowa i krajowa implementacja międzynarodowego prawa humanitarnego, [w:] Prawo międzynarodowe, europejskie i krajowe - granice i wspólne obszary. Księga Jubileuszowa dedykowana Profesor Genowefie Grabowskiej, red. B. Mikołajczyk, J. Nowakowska-Małusecka, Wydawnictwo Uniwersytetu Śląskiego, Katowice 2009, s. 386-408.

34 I Protokół dodatkowy w: Dz.U. z 1992 r., nr 41, poz. 175, załącznik.

35 Zob. C. Harwood, op.cit. 
twa ws. ataku na szpital w Kunduzie (data raportu to 21 listopada 2015 r.) ${ }^{36}$. W raporcie stwierdzono, że żołnierze amerykańscy popełnili serię błędów i naruszyli własne Rules of Engagement (RoE) i międzynarodowe prawo humanitarne, jednak nie popełnili zbrodni wojennych, ponieważ nie mieli zamiaru atakowania osób cywilnych i szpitala. Atak ten był niezamierzony; Amerykanie pomylili budynek będący celem ataku ${ }^{37}$. Efektem tych ustaleń jest jedynie dyscyplinarna odpowiedzialność szesnastu amerykańskich żołnierzy zaangażowanych $\mathrm{w}$ atak ${ }^{38}$.

\section{UWAGI KOŃCOWE}

Zbombardowanie szpitala prowadzonego przez organizację pozarządową Lekarze Bez Granic stanowi niewątpliwie tragiczne i smutne wydarzenie. Nie tylko zginęli i ranni zostali ludzie, ale sam szpital przestał działać i ratować życie kolejnym rannym. Na chwilę obecną nie można z całą pewnością stwierdzić, że została popełniona zbrodnia wojenna, wydaje się jednak, że doszło do naruszenia międzynarodowego prawa humanitarnego. Amerykańskie siły zbrojne - zarówno planujący atak, jak i go przeprowadzający - nie podjęli wymaganych prawem środków ostrożności, których celem jest właśnie zapobieżenie takim tragicznym sytuacjom. Planujący atak mają obowiązek sprawdzić czy atakowany obiekt jest celem wojskowym oraz czy atakując legalny cel wojskowy nie wywołają strat w ludności cywilnej i/lub szkód w obiektach cywilnych. Obejmuje to także chronionych rannych i chorych, personel i formacje medyczne. W razie stwierdzenia, że atak na cel wojskowy takie straty i szkody może wywołać, można postąpić

\footnotetext{
${ }^{36}$ Raport jest dostępny na stronie internetowej: https://drive.google.com/file/d/0B1JB4ezu5DNYLWRIeUkwZ1pIdTg/view (dostęp: 9.05.2016).

37 Ibidem, s. 30, 35. Szerzej na ten temat zob. S. Knuckley, A. Parrin, K. Nimmala, US Government Concludes no "war Crimes" in Kunduz Strike, But Fails to Explain Why, Just Security, https://www.justsecurity.org/30831/government-concludes-war-crimes-kunduz-strike-fails-explain/; A. Whiting, Recklessness, War Crimes, and the Kunduz Hospital Bombing, Just Security, https://www.justsecurity.org/30871/recklessness-war-crimeskunduz-hospital-bombing/ (dostęp: 9.05.2016).

${ }_{38}$ J.D. Ohlin, Was the Kunduz Hospital Attack a War Crime?, Opinio Juris, http://opiniojuris.org/2016/05/01/was-the-kunduz-hospital-attack-a-war-crime/ (dostęp: 9.05.2016).
} 
:::: Agnieszka Szpak, Ocena ataku na szpital w Kunduzie...

dwojako. Jeżeli straty te nie będą nadmierne w stosunku do oczekiwanej bezpośredniej korzyści wojskowej z ataku na cel wojskowy, to atak można przeprowadzić, natomiast jeśli będą nadmierne, ataku nie można przeprowadzić, a rozpoczęty należy przerwać. Nie istnieje żaden algorytm pozwalający określić proporcjonalność, jest to niezwykle trudne zadanie, lecz nie ma dla tego alternatywy. Ponadto, w moim przekonaniu wszelkie wątpliwości w tym zakresie należy rozstrzygać na korzyść wzmocnionej ochrony osób cywilnych, rannych i chorych, jak i personelu medycznego. Biorąc pod uwagę znane nam na chwilę obecną fakty, w tym raport ze śledztwa przeprowadzonego przez amerykańską administrację, można stwierdzić, że USA naruszyły reguły międzynarodowego prawa humanitarnego.

AgNIESZKa SZPAK

\section{Evaluation of the atTACK ON THE KUnduz hospital IN THE LIGHT OF INTERNATIONAL HUMANITARIAN LAW}

The article concentrates on the recent US attack on a hospital led by the international non-governmental organization Médecins Sans Frontières. The hospital was located in Kunduz in Afghanistan and the attack took place on October 2, 2015. The author briefly analyses the legality of the attack in the light of international humanitarian law, especially in the light of the rules of targeting military objectives. 